(REVIEW ARTICLE)

\title{
Acalypha wilkesiana: prospects as an agricultural biocide
}

\author{
Oso Adeola Abiola * \\ Department of Plant Science, Faculty of Agriculture and Natural Sciences, University of the Free State, Qwaqwa Campus, \\ Private Bag: x 13, Phuthaditjhaba 9866, Republic of South Africa.
}

Publication history: Received on 13 April 2020; revised on 20 April 2020; accepted on 22 April 2020

Article DOI: https://doi.org/10.30574/wjarr.2020.6.1.0102

\begin{abstract}
The dynamism of global trade and a changing climate has aided the threats posed by plant pests and diseases on food security. Combating the long-standing challenges posed by pests and diseases has been a frontline issue among the various stakeholders in the agricultural food value chain. Investment in newer synthetic pesticides with increased selectivity towards target pests and decreased toxicity to mammals, the introduction of genetically-modified crops, and development of automated technology for early detection and monitoring of pest population are some 21st-century research advancements to curb the menace. In Africa, agriculture lies majorly in the hands of smallholding farmers, and most of them live below the poverty line and cannot afford these expensive modern technologies. Documented reports over decades have also revealed that the average farmer in Africa relies solely on the use of synthetic pesticides to combat pests and disease problems. Their complacency and indiscriminate application of synthetic pesticides have resulted in deleterious impacts on non-targeted organisms, human health, and the environment. The clarion call has been towards the search for panaceas which eschew the use of synthetic pesticides and promote food safety and security. Plants have been documented with an extensive reservoir of under-tapped and un-tapped bioactive compounds for chemical and biological studies. These plants have been proven efficacious in the management of crop pests and diseases, are readily biodegradable, and with low toxicity on non-target organisms. Acalypha wilkesiana is one of these plants whose information on its application as an agricultural biocide is limited. Therefore this review explores available information on the broad spectrum potentials embedded in the plant, intending to promote its application as an agricultural biocide.
\end{abstract}

Keywords: Acalypha wilkesiana; Biocide; Bioactive compounds; Diseases; Panacea; Pests; Prospects

\section{Introduction}

Acalypha wilkesiana commonly known as copperleaf and Jacob's coat [1] is an erect or spreading evergreen shrub in the family of Euphorbiaceae. The plant can grow up to 2 - 4 metres tall and can occasionally reach 6 metres [2]. The genus acalypha comprised about 450-462 species [3] distributed majorly in the tropics and subtropics, with about 60 per cent of the species native to America and about 30 per cent in Africa [4]. A. wilkesiana is valued for its wide range of variegated cultivars and is often grown as a hedge. The plant thrives in moist, average to moderately fertile, well-drained soil. The best foliage colour is produced when the plant is exposed to full sun. In areas without a pronounced dry season, the plant can flower and produce fruits all year round. The stem is erect with many branches; the branches have fine hairs with a closely arranged crown. The leaves are elliptic to broad ovate with a serrate or coarsely toothed margin, up to $20 \mathrm{~cm}$ long and 10 to $15 \mathrm{~cm}$ wide and 5 to 7 nerved from the base. They are green, copper or bronze variously mottled with different shades and patterns of purple, red, pink, yellow, cream or white. The flowers are reddish in spikes of 10 - 20 at the end of branches. They have separate male and female flowers on the racemes beneath the foliage of the same plant. The male flowers hang downward and are long in spike while the female flowers are in short spikes and often hidden among the leaves. The fruits are small, 3-lobed capsules containing numerous hard, small seeds. The plant often

\footnotetext{
* Corresponding author: Oso Adeola Abiola Email: 2019011440@ufs4life.ac.za
} 
escapes cultivation and has become widely distributed in open sites, in gardens, along the roads and in villages all over the world.

Common names: Copperleaf, Calico, Bush, Beefsteak Plant, Fire Bush, Fijan Fire Plant, Jacob's Coat

Latin name: Acalypha wilkisiena

\section{Varieties of Acalypha wilkisiena}

There are many varieties of A. wilkisiena, and these available varieties vary in height from 1 to 3 metres with different leaf forms and colour:

A. 'Cherry Chocolate': it grows to about $3 \mathrm{~m}$ tall and has large, dark brown leaves that are mottled with red.

A. godseffiana: it has narrow, drooping leaves with cream-coloured margin.

A. 'Java Yellow': it grows to about $1.5 \mathrm{~m}$ tall and has striking medium-sized golden leaves.

A. tropica: it grows to about 1-2 $\mathrm{m}$ tall and has leaves in tones of red.

A. musaica: it has leaves that are mottled with orange and red colours.

A. macrophylla: it has larger leaves, variegated with bronze, cream, yellow and red colours.

A. wilkesiana 'Marginata': it has coppery-green leaves with pink or crimson margins.

A. 'Ivy's Jungle Joy': it grows to about $2 \mathrm{~m}$ tall with large green leaves that are mottled with bright red colour.

A. 'Pink Sport': it grows to about $2 \mathrm{~m}$ tall and has coppery leaves that are veined with a shade of pink.

A. 'Sunset Hue': it grows to about $1 \mathrm{~m}$ tall and has leaves mottled with pink, green and yellow colours.

\section{Scientific classification of A. wilkesiana}

$\begin{array}{ll}\text { Kingdom } & \text { Plantae } \\ \text { Order } & \text { Malpighiales } \\ \text { Family } & \text { Euphorbiaceae } \\ \text { Genus } & \text { Acalypha } \\ \text { Species } & \text { A. wilkesiana }\end{array}$

\section{Traditional application of $A$. wilkesiana}

In Trinidad, the leaf-poultice is used to treat headache, cold and swellings [5]. The seeds are also used to treat breast tumours in South-West, Nigeria [6]. In Malaysia, the leaves are used for the treatment of inflammation, headache, and flu, while the roots are boiled to wash haemorrhoids [7]. In some parts of Africa, the shoots without flowers are cooked as vegetables, in making baskets and as animal fodder. In Nigeria, the water extract of the reddish form is used treating skin problems, especially among the infants $[8,9]$. In some parts of Asia and Papua New Guinea, the leaves are squeezed into the water, and the resulting juice is drunk as a treatment for diarrhoea and dysentery. The fresh young leaves combined with the leaves of Ocimum bacilium, Hibiscus rosa-cynensis, and Euodia hortensis are placed in a bowl of hot water and the vapour released is breathed in to bring relief from pneumonia, malaria, pain and fever [2]. In Britain, the leaves are used to treat diarrhoea. In India, the leaves decoction is used for the treatment of various ailments [10]. In Fiji, the leaves are squeezed and mixed with water, and drunk to regulate menstruation with leaves decoction also used to treat gastritis and lymphoid swellings. In Central America, fresh leafy branches are externally applied to induce perspiration and also to relieve rheumatic pains, inflammations and swellings [11].

\section{Phytochemical composition of Acalypha wilkesiana}

Saponins, tannins, anthraquinan and glycosides have been reported to be in the leaves of $A$. wilkesiana [12]. Earlier, Adesina et al., [13] reported the presence of garlic-acid, corilagin, geranin, quercentin, 3-0-rutinoside and kaempferol in the leaves of $A$. wilkesiana. Elemental analysis of an aqueous extract of $A$. wilkesiana indicated the presence of macro and micronutrients [14]. In a preliminary screening of the leaves of $A$. wilkesiana, Ikewuchi et al. [15] reported the presence of alkaloids, carotenoids, flavonoids (catechins and flavones), saponins and tannins. Kingsley et al. [16] did a 
study using three extracts, namely ethanol, aqueous and dried powder of $A$. wilkesiana leaves to determine the phytochemical constituents in the leaves. They reported the presence of tannins, phenols, saponins, cardiac glycosides, alkaloids, oxalate and terpenoids in the ethanol and aqueous extracts as well as in the powdered leaves. Studies on phytochemical compounds in ethanol extracts of A. wilkesiana using GCMS analysis revealed the presence of 12 compounds. These compounds include 3-Methylene-1-vinyl-1-cyclopentene, 2-Vinylbicyclo[2. 2. 1] hex-2-ene, Acetophenone, Butane-1, 4-diol, 3-Methyl-6-hepten-1-ol, acrylic acid butyl ester, n-Hexadecanoic acid, 1, 4-Dimethyl benzene, Styryl alcohol, Phenylethyl alcohol, 2-Ethyl-1-hexene, and 2-Butenyl propionate [17]. The ethanolic extracts of the leaves, stem bark and root bark of $A$. wilkesiana using GS-MS analysis identified 25 major bioactive compounds. The identified compounds included four major classes of compounds, namely fatty acids and fatty acid esters, phytols, xanthones and sterols [18].

\section{Ethnomedicinal use of $A$. wilkesiana}

Researchers have documented a wide range of healthcare practices that are based on the unique culture of indigenous groups of people or based on their native intelligence. These studies have extensively established the pharmacological potential of the plant, $A$. wilkesiana and justified its use in traditional medicine for the treatment of diseases.

\subsection{Antimicrobial activity}

Akinyemi et al., [8] evaluated crude and ethanol extracts of Phylantus discoideus, Ageratum conyzoides, Terminalia avicennioides, Bridella ferruginea, Acalypha wilkesiana and Ocimum gratissimum against Methicillin-resistant Staphylococcus aureus. The study revealed that the minimum bactericidal concentration (MBC) and minimum inhibition concentration (MIC) of these plants ranged from 30.4-37.0 $\mu \mathrm{g} / \mathrm{ml}$ and 18.2-24.0 $\mu \mathrm{g} / \mathrm{ml}$, respectively. A high MBS value was found in A. conyzoides and B. ferruginea while P. discoideus, T. avicennioides, A. wilkesiana and 0. gratissimum contained traceable amounts of anthraquinones. Thus, their study provided scientific support for the use of P. discoideus, T. avicennioides, A. wilkesiana and O. gratissimum against methicillin-resistant Staphylococcus aureus based diseases. Madziga et al. [19] reported that the aqueous leaf extract of A. wilkesiana contains pharmacologically useful principles elements which could play vital roles in disease management. Onocha and Olusanya [20] established the potency of $A$. wilkesiana as an anthelmintic and antimicrobial agent. Oluduro et al., [21] investigated in-vitro antibacterial effects of aqueous, ethanol, methanol and petroleum-ether of extracts of A. wilkesiana leaves on some gastrointestinal tract pathogens and bacteria, causing skin infection in neonates. They reported that the antibacterial activity of the various extracts of A. wilkesiana leaves was comparable to the reference antibiotics. They submitted that A. wilkesiana leaf possessed inhibitory properties which justifies the folklore uses of the leaf for the treatment of gastroentritis and skin infections in neonates. Aboaba and Omotoso [22] reported the toxicity of the essential oil from the leaves of $A$. wilkesiana against brime shrimps larvae (Artemia salina) and its larvicidal activity against mosquito in south-west Nigeria. Majekodunmi and Nubari [9] reported that the dried leaves of ethanol extract of $A$. wilkesiana possess antimicrobial activity and can be formulated into a suitable cream for the treatment of skin infections. Anokwuru et al. [23] characterized the secondary metabolites responsible for antibacterial and antioxidant activities of $A$. wilkesiana. All the four isolated compounds showed bacterial activity against extended-spectrum betalactamase-producing Klebsiella pneumonia (700603) while one compound exhibited antioxidant activity (IC50 53 $\mu \mathrm{g} / \mathrm{mL})$.

\subsection{Therapeutic activity}

Oyelami et al., [24] treated 32 Nigerians who had a history of mycological as well as clinical evidence of mycoses with the ointment. They reported that the ointment successfully controlled the mycoses in 73 per cent of the affected patients and concluded that $A$. wilkesiana ointment could be used to treat superficial mycoses. Ikewuchi et al., [15] reported that the presence of phytochemical constituents, as well as high crude fibre, protein, and lipids contents in the leaf, support the medicinal use of the plant. Also, this unveils the possibility of the plant as a potential source of food nutrients and nutraceuticals. Alli-Smith et al., [25] investigated the effect of aqueous extract of A. wilkesiana on some enzyme activities and metabolites in the liver and kidney of albino rats. They reported that the administration of the aqueous extract significantly reduced enzyme activities in the liver and kidney and that prolonged usage of the aqueous extract could exhibit dose-dependent toxicity. They also reported that the aqueous extract exhibited transient hypoglycemic effect. The analgesic, anti-inflammatory, anti-pyretic as well as anti-ulcer potential of ethanol extracts of $A$. wilkesiana leaves was investigated in rats. The results showed that the extract produced dose-dependent and significant analgesic and anti-inflammatory activities. The extract also significantly reduced the pyretic states of the animals and protected them against ethanol-induced ulcer [26]. Quds et al. [27] explore the antiemetic activity of methanol extracts of Acalypha fimbriata Schumach. \& Thonn., Acalypha ornata Hochst., and Acalypha wilkesiana cv. godseffiana Muell Arg. They reported that all the extracts showed an antiemetic effect with the reference drug chlorpromazine. Iyamu et al. [28] investigated the lethal dose and the impact of the effective dose of ethanolic leaf extract of $A$. wilkesiana on body weight 
in adult Wistar rats. They reported that the leaf extract might be useful in the management of obesity. Omage and Azeke [29] investigated the medicinal potential of $A$. wilkesiana leaves. Their study revealed the presence of medicinally active compounds such as tannin, phenol, saponins, flavonoid, alkaloids, oxalate, steroids, terpenoids, in the leaves of $A$. wilkesiana. These compounds have been reported effective in the treatments of hypertension and oedema [30], in the management of hypercholesterolaemia and hyperglycemia [31], in the treatment of malaria and cancer. In a study conducted to evaluate the therapeutic benefits of oral administration of extracts of $A$. wilkesiana leaves to manage cardiovascular disease. Thirty experimental rabbits in groups A to E were used for the study. Rabbits in groups A to D were fed with salt loaded diets while group E rabbits served as the control without any diets or treatments. Groups B and $\mathrm{C}$ were treated with aqueous and ethanol extracts of $A$. wilkesiana, respectively. Group A was continuously fed with the salt loaded diets while rabbits in group D were initially fed with the salt loaded diets but was discontinued. The result of the blood samples of the rabbits after 70 days of salt loading diet and a week of oral administration of $A$. wilkesiana extracts revealed that the groups treated with the extracts had lower levels of cholesterol, LDL- cholesterol, and higher triglycerides, HDL-cholesterol levels (Omage et al., 2018). In a non-comparative study aimed at evaluating the safety and efficiency of $A$. wilkesiana ointment. Imaobong and Uwakmfon [32] carried out a phytochemical screening of $A$. wilkesiana leaves. Their results affirmed previous studies that the presence of the phytochemical constituents in the leaf of $A$. wilkesiana authenticates its ethnopharmacological uses in the treatment of different illnesses. Anokwuru et al., [33] investigated the chemoprotective activity of aqueous leaf extract of $A$. wilkesiana against cyclophosphamideinduced toxicity in albino rats. They reported that the aqueous leaf extract of $A$. wilkesiana protected tissues against cyclophosphamide-induced oxidative damage. Chuemere et al., [34] evaluated the effect of hydro methanolic leaf extract of $A$. wilkesiana on pyrexia, pain and inflammation in Wistar rats. They reported that the extract elicited a pain-relieving effect which is an indication of its anti-inflammation, analgesic and anti-pyretic potentials.

\section{Agricultural use of $A$. wilkesiana}

\subsection{Fungicidal activity}

Ogbo and Oyibo [35] reported that ethanol extracts of Ocimum gratissimum, Acalypha wilkesiana and A. macrostachya significantly reduced the radial growth of the fungal Cercospora purpurea infecting avocado (Persea Americana). Akinde et al., [36] investigated comparative effectiveness of chemical biocides and $A$. wilkesiana against post-harvest fungal deteriogens of sweet orange fruits. They reported that the extract did not show any activity against isolated fungal deteriogens. Draz et al., [37] tested extracts from five plants, namely Lawsonia inermis, Acalypha wilkesiana, Melia azedarach, Punica granatum and Lantana camara as inducers to protect wheat against leaf rust infection. Their results indicated that all the plant extracts could induce wheat resistance to the leaf rust Puccinia triticina.

\subsection{Insecticidal activity}

The potential of crude and fractions of A. wilkesiana oil extract was tested against cowpea beetle Callosobruchus maculatus at 20, 30, 40 and $50 \mu \mathrm{l}$ dosages in triplicates [38]. They reported that the oil extract had proven biotoxic activity against C. maculatus, although toxicity was dosage and exposure time-dependent. Acalypha wilkesiana is one of those plants widely promoted for its biologically active chemical constituents with remarkable potency against microbes. Nagoto et al., [39] investigated the attractive potential of granulated bait of $A$. wilkesiana leaves versus citrus pulp to leaf-cutting ants. They reported that the copperleaf baits were less attractive than the citrus-based baits. Oni et al., [40] investigated the insecticidal and toxicological effect of n-hexane leaf extract of A. godseffiana on adult Rhizopertha dominica and albino rats respectively. They reported that the leaf extract proved high insecticidal potential against the infection of $\mathrm{R}$. dominica as it caused a high mortality rate of the insect, reduced the emergence of the adult beetle and caused the inability of the insect to cause weight loss of the treated wheat grains. Their study also corroborates other documented reports on the non-toxic potential of $A$. wilkesiana since no hepatoxic effects were recorded on the experimental animals. Hence their submission that it can be introduced into pest management strategies. Oni [41] investigated contact and fumigant bioactivity of ethanolic oil extract of $A$. wilkesiana on survival and immature stages of C. maculatus as well as damage to seeds and weight loss of protected cowpea seeds. She reported that the oil had toxicity effects on the oviposition and adult emergence of the insect. The fumigant toxicity of the oil also prevented seed damage and weight loss by C. maculatus.

\subsection{Nematicidal activity}

Olaniyi [42] investigated the trend in plantain growth response, and nematode population density build up in response to paring, red acalypha leaf extract, hot water, and boiling water dip. She reported that treatment of pared suckers in red acalypha leaf extract for 5-15 minutes conferred protection against plant-parasitic nematodes. Oso and Olaniyi [43] investigated the potency of red acalypha leaf extract in pared and non-pared plantain suckers. They reported that the complimentary use of the leaf extract with the paring technique inhibited the incidences of banana weevil and plant- 
parasitic nematodes. In a study on nematicidal effects of $A$. wilkesiana against plantain corm damage by plant-parasitic nematodes, Oso et al. [44] reported reduced incidence of dead roots and root necrosis on plantain suckers treated to the leaf extract. Oso [45] carried out a comparative study to determine the effects of some precautionary measure (boiling water, red acalypha plant extract and furadan) against stem borer infestation in a newly cultivated field concerning growth and yield of plantain. She reported that vegetative growth and bunch yield were enhanced among red acalypha treated plants.

\subsection{Antibacterial activity}

Awe et al., [46] screened ethanolic extracts of seven medicinal plants including $A$. wilkesiana against Streptococus sp., Bacillus cereus, Klebsiella sp., Enterobacter aerogenes and Escherichia coli (isolated bacteria from fish). They reported that the extract of $A$. wilkesiana had a broad-spectrum of antibacterial activity against all the tested organisms.

\section{Conclusion}

Phytochemical and biological investigations by various research groups across the world have confirmed that Acalypha wilkesiana possess active constituents with a broad spectrum of activity. The broad spectrum of activity ranges as antifungal, antioxidant, antibacterial,anthelmintic, anti-hypertensive, anti-obesity, anti-malaria, antiemetic, anti-cancerous, and diuretic activities. These activities of $A$. wilkesiana have been widely documented for clinical, scientific and pharmacological use to justify its use in traditional health practices. In agricultural pest management approaches, especially with the use of botanical pesticides, documented information on A. wilkesiana are limited. More research into the biocide potential of $A$. wilkesiana needs to be explored in order to provide sufficient information and evidence regarding its efficacy as a potent agro-biocide.

\section{Compliance with ethical standards}

\section{Acknowledgments}

The author acknowledges The University of the Free State for the support provided by facilitating access to bibliographic databases.

\section{Disclosure of conflict of interest}

The author has declared that no competing interest exists.

\section{References}

[1] RHS Plant Finder. United Kingdom. (2017). Royal Horticultural Society, 960.

[2] WHO. (2009). Medicinal plants in Papua New Guinea. World Health Organization.

[3] Steinmann VW and Levin GA. (2011). Acalypha herzogiana (Euphorbiaceae) the correct name for an intriguing and commonly cultivated species. Brittonia, 63(4), 500-504.

[4] Duman T and Terzioglu S. (2009). Acalypha (Euphorbiaceae): a new genus record for Turkey. Phytologia Balcanica, 15(2), 171-173.

[5] Burkill HM. (1985). The useful plants of West Tropical Africa, 2.

[6] Bussing A, Stein GM, Herterich-Akinpelu I and Pfuller U. (1999). Apoptosis-associated generation of reactive oxygen intermediates and release of pro-inflammatory cytokines in human lymphocytes and granulocytes by extracts from the seeds of Acalypha wilkesiana. Journal of Ethnopharmacology, 63, 301-309.

[7] Ong HC. (2006). Tanaman Hiasan: Khasiat Makanandan Ubatan. Utusan publication, Kuala Lumpur.

[8] Akinyemi KO, Oladapo 0, Okarawa CE and Fasure KE. (2005). Screening of crude extracts of six medicinal plants used in South-west Nigeria unorthodox medicine for anti-methicillin resistant Staphylococcus aureus activity. BMC Complementary and Alternative Medicine, 5-6.

[9] Majekodunmi SO and Nubani SE. (2014). Formulation of Acalypha wilkesiana Muell. Arg. Ethanol leaf extract into creams for the treatment of microbial skin infection. International Journal of Pharmaceutical Science Invention, $3(10), 45-53$. 
[10] Bonsu AK. (2012). Healing with simple plants, radiant health Publication, New Delhi, India.

[11] Omage K, Azeke MA and Omage SO. (2018). Evaluation of the efficacy of Acalypha wilkesiana leaves in managing cardiovascular disease risk factors in rabbits exposed to salt loaded diets. Clinical Phytoscience, 4(1).

[12] Oladunmoye MK. (2006). Comparative evaluation of antimicrobial activities and phytochemical screening of two varieties of Acalypha wilkesiana. Trends in Appl. Sci. Res., 1, 538-541.

[13] Adesina SK, Idowu O, Ogundaini AO, Oladimeji H, Olugbade TA, Onawunmi GO and Pais M. (2000). Antimicrobial constituents of the leaves of Acalypha wilkesiana and Acalypha hispida. Phytotherapy Res, 14, 371-371.

[14] Robert KM, Daryl KG, Peter AM and Victor WK. (2000). Harper's Biochemistry, 25th Edition Large Medical Book, 209-210.

[15] Ikewuchi CJ, Ikewuchi CC, Onyeike EN and Uwakwe AA. (2010). Nutritional potential of the leaves of Acalypha wilkesiana 'Godseffiana' Muell Arg. J. Appl. Sci. Environ. Manage, 14(3), 21-24.

[16] Kingsley O, Marshall AA, Inegbose II and Meg IA. (2013). Phytochemical, proximate and elemental analysis of Acalypha wilkesiana leaves. Scientific Journal of Pure and Applied Sciences, 2(9), 323-331.

[17] Igwe KK, Madubuike AJ, Otuokere IE, Chika Ikenga and Amaku FJ. (2016). Studies on medicinal plant Acalypha wilkesiana ethanol extract phyto components by GCMS analysis. Global Journal of Science Frontier Research, 16(1), 49-55.

[18] Oyebode OA, Erukainure OL, Koorbanally NA and Shahidul-Islam MD. (2018). Acalypha wilkesiana 'Java white': Identification of some bioactive compounds by GC-MS and their effects on key enzymes linked to type 2 diabetes. Acta Pharm, 68, 425-439.

[19] Madziga H, Saka S and Sandabe UK. (2009). Phytochemical and elemental analysis of wilkesiana leaf. Journal of American Science, 66(1111), 510-514.

[20] Onocha PA and Olusanya TO. (2010). Antimicrobial and anthelmintic evaluation of Nigerian Euphorbiaceae Plants 3: A. wilkesiana. Afr. Sc., 11, 85-89.

[21] Oluduro AO, Bakare MK, Omoboye OO, Dada CA and Olatunji CI. (2011). Anti-bacterial effects of extracts of Acalypha wilkesiana on gastrointestinal tract pathogens and bacteria causing skin infections in neonates. Ife Journal of Science, 13(2), 371-380.

[22] Aboaba S and Omotoso 0. (2012). Chemical constituents, toxicity and larvicidal activity of the essential oil from the leaves of A. hispida and A. wilkesiana in south-west Nigeria. Elixir Appl. Chem., 52, 11263-11265.

[23] Anokwuru CP, Sinisi A, Samie A and Taglialatela-Scafat O. (2015). Antibacterial and antioxidant constituents of Acalypha wilkesiana. Natural Product Research, 29(12), 1180-1183.

[24] Oyelami OA, Onayemi O, Oladimeji A and Onawunmi O. (2003). Clinical evaluation of Acalypha ointment in the treatment of superficial fungal skin diseases. Phytotherapy Research, 17, 555-557.

[25] Alli-Smith YR, Adanlawo IG, Aluko BT and Omoluabi IO. (2011). Effect of aqueous extract of Acalypha wilkesiana (Copperleaf) on some enzyme activities and metabolites in the liver and kidney of albino rats. J. Nat. Prod. Plant Resour., 1(3), 70-74.

[26] Owoyele BV, Okoye OC, Dolor RO, Oloruntola OP and Soladoye AO. (2011). Analgesic, anti-inflammatory and antipyretic effects of the ethanol extract of Acalypha wilkesiana leaves in rats. Niger J Physiol Sci, 26(1), 77-82.

[27] Quds T, Ahmed S, Ali MS, Onocha PA and Iqbal A. (2012). Antiemetic activity of Acalypha fimbriata Schumach. \& Thonn., Acalypha ornata Hochst., and Acalypha wilkesiana cv godseffiana Muell Arg. Phytopharmacology, 3(2), 335-340.

[28] Iyamu OA, Ugheoke AJ, Ozor OM, Airhomwabor KO and Uwuigbe M. (2014). A murine model study on the antiobesity potentials of ethanolic leaf extract of Acalypha wilkesiana. International Journal of Herbs and Pharmacological Research, 3(2), 34-39.

[29] Omage K and Azeke AM. (2014). Medicinal potential of Acalypha wilkesiana leaves. Advances in Research, 2(11), 655-665.

[30] Haslem E. (1989). Plant polyphenols: Vegetable tannins revisited- chemistry and pharmacology of natural products. Cambridge University Press. 169. 
[31] Francis G, Zohar K, Haninder PSM and Klaus B. (2002). The biological action of saponins in animal systems: A Review. British Journal of Nutrition, 88(6), 581-605.

[32] Imaobong ED and Uwakmfon AE. (2019). Phytochemical screening to validate the ethnobotanical importance of Acalypha wilkesiana leaves. Journal of Medicinal Plants Studies, 7(9), 269-273.

[33] Anokwuru CP, Anyasor GN, Shokunbi OS, Sopekan B, Osinuga OK, Afolabi OE, Arojojoye OB, Ezekiel CN and Ramaite ID. (2019). Chemoprotetive activity of aqueous leaf extract of Acalypha wilkesiana against cyclophosphamide-induced toxicity in rats. Asian Pacific Journal Tropical Medicine, 12, 409-415.

[34] Chuemere AN, Aniyeloye MA, Olorunfemi OJ and Bekinbo MT. (2019). Effect of hydro-methanolic extract of Acalypha wilkesiana leaves on pyretic, inflammatory and pain-induced scenario in Wistar rats. International Journal of Pharma Sciences and Research, 10(10), 350-355.

[35] Ogbo EM and Oyibo A. (2008). Effects of three plant extracts (Ocimum gratissimum, Acalypha wilkesiana and Acalypha macrostachya) on post-harvest pathogen of Persea Americana. Journal of Medicinal Plants Research, 2(11), 311-314.

[36] Akinde SB, Adeniyi MA, Adebunmi AA, Oluwajide 00 and Ogunnaike 00. (2017). Comparative effectiveness of chemical biocides and Acalypha wilkesiana leaf extract against post-harvest fungal deteriogenes of sweet orange (Citrus sinensis) fruits. Egyptian Journal of Basic and Applied Sciences, 4(2), 143-152.

[37] Draz IS, Elkhwaga AA, Elzaawely AA, El-Zahaby HM and Ismail AA. (2019). Application of plant extracts as inducers to challenge of leaf rust of wheat. Egypt J Biol Pest Control, 29(6), 1-8.

[38] Oni MO, Olatujoye KS, Ogungbite OC and Ofuya TI. (2018). Potential of crude and fraction of Beefsteak plant, Acalypha wilkesiana Muell Arg oil extract to Callosobruchus maculatus (Coleoptera: Bruchidae). Journal of Entomology and Zoology Studies, 6(6), 187-193.

[39] Nagamoto NS, Barbieri RF, Forti LC, de Sousa Cardodo SR, Moreira SM and Santos Lopez JF. (2011). Attractiveness of copper leaf-based bait to leaf-cutting ants. Ciêccia Rural, 41(6), 931-934.

[40] Oni MO, Ogungbite OC, Makinde VG, Iroba IF, Igbe FO, Lawal OA and Ofuya TI. (2019). Insecticidal and toxicological study of $n$-hexane leaf extract of A. godseffina used as protectant for wheat grains. European Journal of Zoological Research, 7(1), 19-25.

[41] Oni MO. (2019). Efficiency of Acalypha wilkesiana (Muell Arg.) leaf oil extract applied as biocide against Callosobruchus maculatus (F.) (Coleoptera: Bruchidae). Brazillian Journal of Biological Sciences, 6(12), 171-180.

[42] Olaniyi MO. (2014). Effect of Acalypha wilkesiana leaf extract, hot and boiling water on plantain growth trend and soil nematode densities. Journal of Biology, Agriculture and Healthcare, 4(18), 105-115.

[43] Oso AA and Olaniyi MO. (2014). Potency of red acalypha leaf extract against pests in pared and non-pared plantain suckers. Nigerian Journal of Nematology, 2, 63-72.

[44] Oso AA, Longe 00 and Olaniyi MO. (2016). Nematicidal effects of red acalypha (Acalypha wilkesiana) on plantain yield and corm damage by nematodes. International Journal of Agriculture and Environmental Research, 2(3), 549-557.

[45] Oso AA. (2017). Comparative effects of some sanitation methods on growth and yield of false horn plantain in Ekiti State, Nigeria. Research Journal of Agriculture and Sciences, 5(4), 6-9.

[46] Awe FA, Akinyemi AA, Ezeri GNO and Giwa-Ajeniya AO. (2013). Sensitivity of bacteria isolated from fish to some medicinal plants. The International Journal of Engineering and Science, 2(9), 45-50.

\section{How to cite this article}

Oso AA. (2020). Acalypha wilkesiana: prospects as an agricultural biocide. World Journal of Advanced Research and Reviews, 6(1), 166-172 